\title{
Of kings, jesters and fools: the insignificantly significant role of minor characters in selected isiZulu dramas
}

\author{
C.D. Ntuli \\ Department of African Languages, P.O. Box 392, UNISA, 0003, Pretoria, South Africa \\ ntulicd@unisa.ac.za
}

\begin{abstract}
Of the many critical analyses and articles already written on isiZulu literature that deal with characters, almost all concentrate on the main characters, for instance, the hero. Greater attention is seldom given to the minor characters. Although one could debate that it may be a futile exercise to analyse characters who have no functional part in the fabula because they do not experience functional events, by using examples from two isiZulu dramas entitled Mageba Lazihlonza and Inkinga Yomendo, I will endeavour to demonstrate some key or decisive roles that the minor characters play to keep the text intact and 'make' or 'break' the hero. Contemporary happenings world-wide have borne witness to many events where leaders and prominent people have been brought down a peg or two by their subordinates or by insignificant individuals.
\end{abstract}

\section{Introduction}

In critical literature, it rarely occurs that one comes across an article that concentrates on the portrayal of less important characters. In drama, for instance, it is the hero and/or the antagonist who usually steal the show. Neither in isiZulu literature nor in other African languages, has the author come across an extensive study of the role of minor characters. However, D.P. Kunene (1994) has made some observations about minor characters in his article entitled Characterization, realism and social inequality in the novels of C.L.S. Nyembezi:

The fact that scholars often turn a blind eye to the role of minor characters is quite astounding because writers usually intend a useful purpose for these characters. Are these characters then not a representation of human beings in our society? Does our society not possess such characters? If it does, how does society see them, how do they behave in society and how do they view the society?

I believe that these characters should be given attention because a great deal can be learnt from their actions. Contemporary happenings world-wide have borne witness to many events where prominent figures have been brought down a peg or two by their 'less important' subordinates. Warde (1974:146) highlights the idea of taking every character seriously when he says: 'Don't skip small parts, such as servants, clowns, rustics etc.; read them all.'

Warde (1974:148) further warns against the tendency of frequently neglecting or omitting the minor parts, which are deemed non-essential to the interest of the play:

This is to be deplored; for Shakespeare has placed many of his best thoughts and most pointed epigrams in the mouths of comparatively un-important characters; so that to pass over or neglect these passages is to lose many beauties of thought, much philosophic reflection, and a fund of characteristic humour.

It is precisely for this reason that it was found necessary to look at the significant role played by some minor characters in drama. Their effect on the main characters will also be scrutinized. Furthermore, since literature is generally a reflection of life, real-life events will be used in this article as examples to draw some parallels between the fictitious and the real world.

In this article, texts from two dramas will be used to illustrate the role of minor characters. The title of the first play is Inkinga Yomendo by B.J. Dube. The second is B.B. Ndelu's drama entitled Mageba Lazihlonza. As a point of departure, I will give some background information on each story before proceeding to the delineation of the chosen character. 


\section{Inkinga yomendo}

As the title of the play indicates, this work is about marriage. It dramatizes the immoral and devious ways used by some girls to secure husbands. The story takes place in the semi-rural area of Madazana. Two of the girls, Gezephi and Jabhisa, in their pursuit of marriage, seek help from the local diviner Pelepele and the spiritual healer Dludla. Both these characters, who initially appear to be experts in their professions and who pose as the only ones who could prevent the girls from Madazana from becoming spinsters, turn out to be impostors. The two impostors vanish without a trace as soon as they have helped themselves to money, candles, firewood etc., which served as a form of payment for their services.

The securing of a partner, although it is as old as life itself, continues to be a major undertaking and a vexed issue. Even today, we continue to find some people aspiring to this seemingly evasive ideal. An article that appeared in an issue of the True Love magazine (June 1999:88) bears witness to this. It reads as follows:

\section{Can muthi buy love?}

Women and men of the 90s are still buying love from traditional healers. [...] Corporate executives, television personalities, graduates, ordinary citizens, blacks, whites, Indians and coloureds come pouring in to her consulting rooms to find solutions to their relationship and marriage problems.

Written in the early sixties, Inkinga Yomendo vividly dramatizes the extent to which some girls will go to find a man. The parallel between the event portrayed in literature and events that happen in real life, demonstrates one of the functions of literature, which is to reflect human behaviour to the reader. Kunene (1994:155) explains the relationship and the overlap that exists between fictionalized characters and human beings as follows:

the story is in fiction, not history. It therefore seeks to reflect general attitudes and behaviour traits which just as well could have been carried out by real people. ... fictionalized characters reflect universal human traits, while history, on the other hand, provides individual manifestations of human behaviour.

\section{Character delineation of Mhlupheki}

In Inkinga Yomendo, we come across a minor character called Mhlupheki. No special features distinguish him. In his list of characters, the writer describes him as isilinyana sendawo, 'the local fool'. Even the girls from Madazana call him a fool when they gossip about him. In fact, Mhlupheki does behave like and appears to be a fool because he has a habit of shaking himself from side to side and likes to lick his lips. When he is with girls, he is inclined to keep squeezing them. He sometimes finds pleasure in bumping them hard with his hips. Girls seem to be amused by his funny habits, especially when he lifts up one shoulder and walks sideways like a cock.

The manner, in which the writer has caricatured him, makes him appear to be a fool or a clown but there is more to him than meets the eye. Although people see him as being stupid and dumb, he appears to possess some intelligence and insight to which many people of Madazana are oblivious. However, a man called Gagamela, seems to have noticed that Mhlupheki is not as stupid as he appears. In fact, Gagamela insinuates that Mhlupheki pretends to be stupid so that people will take pity on him and consequently give him some money. This can be witnessed in the dialogue that occurs after Gagamela has asked his sister Khosi to bring Mhlupheki some amahewu. Mhlupheki responds as follows to this offer:

Amahewana endodeni.

Kungesiyo indojeyana 
Ingawaphuza iwathini? (p.46)

'A little bit of mageu for a man

who is not half a man.

How can he drink it?'

(such an insufficiency)

Mhlupheki's response indicates that, although he is regarded as a fool, he is able to weigh facts and also that he thinks highly of himself for he does not regard himself as 'half a man'.

To this, Gagamela answers:

Wena Mhlupheki uzenza isilima ngesimabomu nje. Uhlakaniphe uqedile. Into nje ekhona ufuna ukuphila ngandoda (p.46).

Mhlupheki, you are purposely pretending to be foolish. You are very intelligent. The thing is, you want to be a parasite.'

Gagamela again comments on Mhlupheki's intelligence when he hears him praising his sister, Khosi, for being pure and for having the wisdom to not search for luck from the diviners and spiritual healers. Mhlupheki intelligently muses over and makes up puns about her 'pure blood', which has not been tarnished by the healers. Here he insinuates that Khosi will be married, unlike the other girls who depend on muthi, charm and magical acquisitions to attract men. Gagamela responds with a metaphor to Mhlupheki's words of wisdom:

Mina kade ngambona uMhlupheki lona - insengetshe. (p.47)

T have noticed a long time ago that Mhlupheki is a very sharp stone.'

(Referring to his high level of intelligence.)

Alhough Mhlupheki is peripheral to the story line, is presented as a fool by the writer and is regarded as such by the characters, he plays a significant role in the story. The writer has caused him to represent the ordinary person or an outcast in our communities, the one who is treated with less respect because of his circumstances. It is also worth noticing that the writer has used Mhlupheki as a commentary on the actions, events and characters in the story. He is a character who can think deeply and reflect philosophically on the foolishness of humankind in trying to obtain the seemingly unobtainable by resorting to wayward means, which not only waste money but conversely cause misery and a loss of human dignity. This can be seen in his subsequent speech, which is filled with insightful understanding of human behaviour. In the last scene of Inkinga Yomendo, Dube puts his 'best thoughts and most pointed epigrams into the mouth of this comparatively unimportant character' (Warde, 1974:146) as Mhlupheki soliloquizes about the so-called 'fly-by-night' healer and diviner, who has left his clients in the lurch with empty pockets. He says:

UDludla nokubholofitha kwakhe kuthiwa usehambile;

Amabhodlela amanzi asegcwele umoya,

Izimali zethu nazo kanye naye sezemukile.

Ezikhwameni zonke zakhe nasemigodleni;

Kugcwele izithukuthuku zethu, imijuluko

Ngezandla zethu siyikhiphile ...

Ngesihle, yebo, sayibeka entendeni yezakhe;

Umsulwa okaDludla engazange wasiphoga.

Sasala silula, silugebhezi, silusizi, size;

Kodwa umnyama khuhle, usahlezi nathi.

Wena, ntokazi emhlophe, wawuzwe ngobani na 
Ukuthi, umDali wakho esekudalile wakulolonga,

Nemvelo yakunisela yakukhulisa yakuhlobisa,

Kungabuye kuvele isandla esiyokwemboza,

Ukuqhakaza kwakho kungakhangi? (pp.87-88)

'It is rumoured that Dludla with his prophecies has left,

Water bottles are now filled with air;

Our money has vanished with him,

In all his pockets and in his sacks;

There is a lot of our sweat, the sweat

With our own hands we have given the money away ...

We have voluntarily put it in his palms;

Dludla is blemish free for he did not force us.

We were left with no dignity, left with pain and with nothing;

But bad luck is with us still.

You pure lady, who has ever told you that

After your Creator has made and beautified you,

And Mother Nature has nurtured and decorated you,

There could crop up a hand that can stop

Your beauty from shining and attracting?'

The writer has used Mhlupheki as an internal narrator to reflect on the behaviour of the other characters and bring cohesion into the story. The fact that the lament about the bogus healers is told from Mhlupheki's point of view highlights his significance in the story. One is compelled to ask the question: Why did the writer choose a minor character in his story to spell out words of wisdom? One could argue that the writer could have used Gagamela who, being a policeman, is more intelligent and more conversant with human follies. It could be noted that this minor character, in being made different from the others, has been placed in the foreground.

Human beings are satirized through the character of Mhlupheki. Mhlupheki serves as a reflection of the seemingly 'normal' individuals whose lives are characterized by obscured, blurred and befogged factors and masked or concealed odd behaviours and mannerisms, which are actually part and parcel of the so-called normal individuals. In more ways than one, all human beings are like Mhlupheki, for their ways are crooked, they ukekelisa okweqhude 'walk sideways like a cock' (Dube, 1961:25). The simile of the cock, as used by the writer when he describes Mhlupheki's manner of walking, is apt when we think of the Shakespearean fool's headgear that was shaped like the head and neck of a cock. The cock symbolized the giving away of secrets. In Willeford (1969:6) this is explained as follows:

The cock of the fool's cap (coxcomb) cackles merrily, presumably giving away all the secrets.

This is similar to Mhlupheki's personality: he knows everything about everybody at Madazana and he freely and in jest babbles away everybody's secrets. His personality further signifies what muddled individuals we are and the confused world in which we live, where the unexpected mushrooms unpredictably.

From the soliloquy, it is observed that Mhlupheki appears to be an astute observer of people. He reaches his conclusion because he mingles with and befriends everybody in the community. He is a friend to all the girls - both to those who go to the healers and those who are 'pure'. He goes to visit the diviner and the spiritual healer personally. The people of Madazana end up telling him all their stories because they do not hold him in high esteem or regard him as being a threat. Thus he has first-hand information about almost everyone in the community. 
The story of Inkinga Yomendo is a picture of the reality that we come across in our daily lives. Many impostors arrive under the guise of helping their own black people, but they cheat and exploit them instead and disappear with their hard-earned money. Whether educated or not, many black people fall prey to these impostors. Many stories have been published in newspapers about individuals who manipulate a situation to enrich themselves instead of being of benefit to those in need. One need only think of the 'fly-by-night' schools, contractors, lawyers and bank thieves who steal their clients' money from their bank accounts under the pretext of helping them. To this day, the story of Mr Khalipha (not his real name) that was published in the Tribute magazine is still vivid in the minds of people. Khalipha, with his eloquence and brilliant mind, passed himself off as a financial journalist, investment researcher, businessman and university graduate:

... his penchant for swimming against the political stream drew attention to him in the late ' $80 \mathrm{~s}$, ... when he was not introducing himself as a political analyst, he was trying every method in the book to make money' Tribute magazine (November 1995:48).

However, there are conflicting characteristics and contrasting behaviours between Mhlupheki and Mr Khalipha. While Mhlupheki sometimes used his 'foolishness' for personal gain, it was not done in a corrupt way; Khalipha, on the other hand, used his wit and natural intelligence for the same purpose but in an immoral and unscrupulous manner. He seemed to be fulfilling or enacting what Warde (1974:17) realized when he observed the results of the ever-changing times. Warde comments as follows on the careers of the Shakespearean fools who used buffoonery mixed with wit to entertain their masters in order to make a living:

... folly no longer carries bauble, and the man who is wise enough to wear the motley of the mediaeval fool might don today the robe of the justice, or the toga of the statesman with dignity to the office and honour himself.

Mr Khalipha's actions seem to concur with the above, except that he has donned modern regalia to succeed in his plans.

Lastly, we see that in Inkinga Yomendo, the writer has used a minor character to impart a moral to the reader or hearer of the story. A Zulu proverb condenses this message to: ifa leziwula lidliwa yizihlakaniphi - freely translated it means that 'the wealth of fools will benefit the intelligent.'

\section{Mageba Lazihlonza}

Mageba Lazihlonza is a story about the feud between two of King Mpande's sons: Mbuyaze and Cetshwayo. According to custom, Cetshwayo is supposed to be Mpande's successor, but the king dislikes him because of his obstinacy and insubordination. As Mbuyaze is his favourite, the king resorts to all sorts of tricks and ways to convince the nation that Mbuyaze and not Cetshwayo should be his successor. He tells the nation of his dream, which indicated that Mbuyaze should reign after him. When his chiefs tell him that according to custom, it is Cetshwayo who should be king, he says: Inkosi ayibekwa ngamkhaba kepha ngezikhwepha, meaning that 'custom is not of the essence when it comes to choosing a king, but that the king should show his bravery and strength in order to ascend the throne.'

King Mpande subsequently invites his people to an event where they will witness who is the stronger of the two sons. The sons are expected to lift a cow in the kraal. The first one to succeed in doing so would automatically become king. To the king's disappointment, Mbuyaze is unsuccessful and Cetshwayo does this with ease, but Mpande refuses to acknowledge defeat. In this story we find a peripheral or minor character called Fofobala, who is the king's insila, 'personal servant'. As the story unfolds, Fofobala plays a significant role in upsetting the balance of power in the Zulu nation. He does this by stealing a very important item, which helps to decrease Mbuyaze's powers but which helps Cetshwayo to succeed against all odds. 
In the analysis of Fofobala's character delineation, we observe how Ndelu uses a minor character to voice some concerns about things that are happening in society. In Mageba Lazihlonza, we are shown that King Mpande has been metaphorically used to represent those who have power but who autocratically misuse it and distort information for personal gain in order to suppress their subordinates. The old adage 'power corrupts and absolute power corrupts absolutely' could not be more fitting here. Fofobala on the other hand, is a metaphor for the ordinary man, the oppressed, the muted, but who, when given a platform, has the potential to transform the whole nation and change the disequilibria.

Here another role that is played by Fofobala as a minor character emerges: he provides a contrast between the ruler and the one who is ruled. Gallagher (1997:11) sums up this function well when he says:

Minor characters not only enrich the fictional landscape, then, suggesting other lives we will never fully know at all, but which we could, were the author willing to flesh them out, but their effect on the title character is also often of prime importance.

\section{Fofobala's character delineation}

Fofobala's character is depicted by the work he does: he is insila yenkosi, 'the king's body servant.' Insila literally means 'dirt' or 'body dirt'. His name therefore suggests that he is the recipient of the king's dirt. Among other things, his job description included some of the following (interview with C.T. Msimang, 1999):

Ngokuya ngomsebenzi ewenzayo, insila inceku ethwala insila yenkosi. Kuyamangaza ngoba ikhethwa ngobuqhawe bayo, iba umlindi wenkosi. Uyinsila ngoba uma inkosi inesikhwehlela, insila yenkosi iphelela kuye ... inkosi uma iyogeza insila iba khona. Uma kumele inkosi yelashwe, insila okumele inambithe kuqala yikhona ubuthi buzongena kuyona kuqala uma bukhona. ... Insila ilala emnyango ukuze uma ngabe kufika izitha zifice yona kuqala, ivikela inkosi. Uma inkosi ifa nayo iyafa. Ngoba kwesatshwa ukuthi izokwengama abasele ngesithunzi senkosi, phela sisala kuyo. Ngakhoke insila isondelene kakhulu nenkosi, singathi iyingxenye yayo.

'According to the work he does, the insila is the servant who carries the king's dirt. This is surprising because the insila is chosen for his bravery. The insila becomes the king's personal guard. He is the king's personal servant because when the king coughs out sputum, the king's dirt lands on the insila ... when the king goes to wash himself, it is the insila who attends to him. Should the king fall ill, the insila must taste the medicine first so that he will be the one who is first subjected to the poison should it happen to have been administered in the medicine... The insila sleeps at the door to protect the king in case the enemies launch an attack. When the king dies, the insila is also killed. This is done because it is feared that the insila will overshadow people with the king's dignified bearing, as the bearing does indeed remain with him. Therefore the insila is very close to the king - in fact, we can say he is part and parcel of the king.'

During the interview Msimang voiced his dissatisfaction, and that of other scholars, with the manner in which the author has portrayed King Mpande and Fofobala. He specifically complained about the demeaning manner in which Fofobala, as the king's insila, has been depicted.

From the duties the insila is required to perform, we can see that, although this function is chosen because of its warrior-like charges and prowess, its status is reduced by its duties. Even Mpande does not seem to respect his body servant. This is seen in the manner in which he chases him away when he has visitors:

Lindela phandle Nsila nakuba ulihubuhubu, ihlanga lezindlubu elithandwa yisona kuphela ... Wathalaza Fofobala; awuzwanga ukuthi ngitheni? Ngithe hamba uyofofobala phandle esithumbanjeni ... Thana dlabalanda uhambe uncokola nesithunzi sakho. (p. 13) 
'Wait for me outside Nsila, even though you are a porous, spongy substance, a stalk of the voandzeia nut, which is liked by it alone ... Why do you look hither and thither; didn't you hear what I said? I said you must go and crouch outside ... just go outside and joke with your shadow.'

Fofobala seems to be unhappy about the duties he performs. He constantly complains to one of the king's officials called Sonkehlenkehle; saying:

\section{Nginuka amafinyila nezikhwehlela zayo.}

'I stink of the king's mucus and sputum.'

In his further discussions with Sonkehlenkehle about his discontentment, we are given an ominous foreboding regarding his intention to topple or to undermine the monarchy.

\section{Angimniki lutho uZulu ... ngokukhohlwa konke Sonkehlenkehle kodwa hhayi abathakathi ban- sondo, abathakathi bakwaZulu.}

'I do not give the Zulu nation any chances, ... I will live to forget everything, Sonkehlenkehle, but I shall never forget those treacherous witches, witches from KwaZulu.'

Later in the story Fofobala gets an opportunity to put his vengeful ideas into action when a battle for the throne is to take place between Mpande's favourite son Mbuyaze and his iziGqoza regiments and Cetshwayo and his uSuthu regiments. King Mpande orders a goat to be slaughtered, as he wishes to offer the ingobo, which is a part of the goat's small stomach, as a sacrifice to their ancestors to solicit their support for Mbuyaze to win the battle. Ngqumbazi, one of the king's wives, mother to Cetshwayo, asks Fofobala to steal the ingobo, which he does, and takes it to Zibhebhu, one of Cetshwayo's warriors, who subsequently performs the relevant ritual.

It seems their ancestors are smiling upon them, for Cetshwayo's regiments are successful in killing Mbuyaze's regiments and Cetshwayo kills Mbuyaze. This mission is accomplished because of Fofobala's help. The stealing of the ingobo as a sacrifice to the ancestors for luck is a relevant allusion to the biblical incident (Genesis 28:1-29) where it was Jacob instead of Esau who was blessed by his father, with the help of his mother Rebecca. As in Mageba Lazihlonza, meat from a goat was also used as a form of sacrifice.

As the story proceeds, we learn that Fofobala defects, because he bravely fought alongside Cetshwayo's enemies, brutally killing a number of them.

From the storyline we note that, although Fofobala is presented as a minor or foil character, he plays a deciding role in tipping the scales and in bringing the Zulu kingdom into harmony. As a foil character, Fofobala was supposed to serve the interests of the king by looking after Mbuyaze's interests but instead he turns the tables. He was capable of accomplishing this because he was close to the king; was taken less seriously and also behaved like a fool, while underneath it all, he carried his own grudges, dissatisfactions and hidden agendas. He was well informed and knew the will and wishes of the people who wanted Cetshwayo as the chosen king. On the other hand, King Mpande was too comfortable basking in the glory of his power, which led to his downfall. In fact, Fofobala could have been the one least expected to turn against the king's wishes and interests. To a certain degree, this action taints Fofobala's character because he turns into a traitor. He behaves like Judas Iscariot, someone whose loyalty cannot be trusted. By allowing himself to be coerced by the king's wife into stealing the ingobo, he is depicted as a person who is easily swayed and who is sometimes too obedient and respectful to his seniors.

The story has a parallel in the modern South African situation with President Mandela as a shining example in South African history and to the whole world. The white South African National Party leaders in the 1960s were synonymous with power, autocracy and domination. They ruled black South Africans with an iron hand. They treated them with the utmost denigration and disrespect. But ironically it is the same black people who fought and 
liberated themselves from this harsh rule through the suffering of Nelson Mandela, who was made to languish in jail and to perform parrot-like tasks despite the fact that he possessed great intelligence, aspirations and ideals. Like Fofobala, Mandela was treated with disrespect and with no dignity. Nevertheles he rose above all oppression and, like a true warrior and fighter, liberated his people. But unlike Fofobala, Mandela did not advocate the maiming and the shedding of blood of his enemies. Instead, he held them by the hand and led them into a free and democratic South Africa.

\section{Conclusion}

In this article, we have noted the importance of studying and analysing minor characters. The analysis of minor characters is significant, as these characters give to the reader an indication of human behaviour in real life. These characters form links in the chain of events in the fictitious world. Overlooking these minor but important characters, results in an incomplete analysis of character delineation in the work as a whole. Lastly, the importance of juxtaposing the fictitious world with the real world was highlighted, as experience has taught humankind that 'history illustrates by examples the general truths fiction explores' (Kunene, 1994:155).

\section{References}

American Bible. 1976. Good News Bible: Today's English Version, Society. $9^{\text {th }}$ impr. New York: American Bible Society.

Dube, B.J. 1961. Inkinga Yomendo. Pietermaritzburg: Shuter \& Shooter.

Gallagher, E.J. 1997. The role of minor characters in Flaubert's Madame Bovary. French Studies Bulletin:

Quarterly Supplement 65:7-11.

Kunene, D.P. 1994. Characterization, realism and social inequality in the novels of C.L.S. Nyembezi. South African Journal of African Languages 14(4):155-162.

Ndelu, B.B. 1962. Mageba Lazihlonza. Pietermaritzburg: Shuter \& Shooter.

Tribute Magazine, November 1995.

True love Magazine, June 1999.

Warde, F. 1974. The fools of Shakespeare. Los Angeles: Times-Mirror Press.

Willeford, W. 1969. The fool and his scepter. Evanston: Northwestern University Press. 
Copyright of South African Journal of African Languages is the property of University of Port Elizabeth, Department of African Languages and its content may not be copied or emailed to multiple sites or posted to a listserv without the copyright holder's express written permission. However, users may print, download, or email articles for individual use. 